\begin{tabular}{c}
\hline ACPES Journal of Physical Education, Sport, and Health 1 (1) (2021) \\
ACPES Journal \\
http://journal.unnes.ac.id/sju/index.php/ajpesh \\
\hline
\end{tabular}

\title{
Outdoor Education in Promoting Nature Appreciation: A Survey through Activity Enjoyment among Physical Education Students in a Public University
}

\author{
Mawarni Mohamed ${ }^{\bowtie}$, Siti Nurfatihah Alpandi, Azlan Ahmad Kamal, Ani Mazlina \\ Dewi Mohamed, Zaharul Azwan, Zarizi Abd Rahman, M. Nur Fariduddin, A. Fahim \\ Zulkifli
}

Universiti Teknologi MARA (UiTM) Malaysia, Malaysia

DOI: https://doi.org/10.15294/ajpesh.v1i1.46326

\begin{tabular}{l} 
Article Info \\
\hline Article History \\
Submitted 9 January 2021 \\
Revised 25 May 2021 \\
Accepted 11 June 2021 \\
\hline Keywords \\
Outdoor Education, Nature \\
Appreciation, Enjoyment, \\
Nature-Deficit-Disorder
\end{tabular}

\begin{abstract}
Outdoor Education (OE) is usually associated with challenging activities and developing skills among students. It also teaches learning through the interaction with the nature world which helps to educate for environmental appreciation. Is the frequency of involvement can determine the appreciation among its participants? So, the objectives of this study are to identify the involvement of outdoor activities, its enjoyment of participation and its relationship with nature appreciation among undergraduate students in a higher learning institution in Malaysia. One hundred and sixty-nine $(n=169)$ students who participated in this study were from a Physical and Health Education Program. Results from the study indicated high levels of participation with much pleasure from diverse outdoor activities in water and land based. Pearson's correlation analysis was performed between each type of water and land-based activity with nature appreciation. Analyses were found to have significant relation of several activities with nature appreciation. Findings indicated a significant but weak relationship between the overall activities and nature appreciation among the students. It was suggested that integrating together new area of studies related to mother nature should be incorporated during the activities.
\end{abstract}

\section{INTRODUCTION}

Engaging or participating in any of the outdoor activities is known as partly a hobby and some treat it as an adventurous vacation. In promoting a more exciting and enjoyable experience, parks and services provide places for such activities so people from all walks of life can appreciate what outdoor can serve for both physical and social setting. Students in schools and in higher levels are encouraged to participate in outdoor adventure as part of their past time or as organized activities in their organizations.

Outdoor education (OE) programs usually provide organized exposure to outdoor adventure activities to help promote intrapersonal and interpersonal development (Booth \& Neill, 2018).

\footnotetext{
Correspondence Author:

Kampus Puncak Alam Selangor Malaysia

e-ISSN 2797-0426

E-mail: mawarnim@uitm.edu.my
} 
Outdoor education is usually related with adventurous and challenging activities with some risks, where participants or students learn new skills through experiential and activity-based learning. Outdoor education is a unique process to develop students' skill, knowledge, sportsmanship, well-being, appreciation to nature and environment. Most of the outdoor learning takes place in a versatile authentic learning environment such as lakes, forest, sea, mountain, and wilderness. Outdoor education also teaches learning through the interaction with the nature world. Besides, it plays an important role to educate students on the basic skills of survivors.

However, a place where activities with nature orientation are not given much priority because environmental education and natural studies are not emphasized in schools and in higher learning institutions in Malaysia. Therefore, outdoor activities are aimed to educate the students in appreciating every inch of nature as part of their good value towards their wellbeing. Nature itself has given a sound a relief. Priest (1990), notes that the aims of the outdoor education program should be to help raise awareness and to develop relationships (intrapersonal) with others (interpersonal) and with the outdoor environment (ecological).

Hence, efforts will also be undertaken to increase children's access to quality education in order to enhance their ability to aid behavioral improvements and social interaction, as well as to promote their mental growth through interacting with nature (Hussein, 2010). According to Michelsen \& Fisher (2017), environmental education has been proven as an effective tool to shift the perceptions and behaviors of individuals towards more sustainable ones. The learner gains a better understanding and acknowledges the importance of building a relationship between human and nature. Thus, benefit us to face all the environmental crisis. Outdoor experiences, especially educational experiences, increase the enthusiasm of students for nature, interaction with nature, and willingness to engage in environmental activism (Abdullah, Zakaria, \& Razman, 2018).

Studies have also shown that learning about the world directly from nature has a stronger effect on learning the subject matter, offers awareness and a deeper sense of suitable interconnections that occur in nature and can affect behaviours, interests, and motivation (Nadelson \& Jordan, 2012). Other than that, students challenge themselves to do outdoor activities, such as climbing rocks, and learn to communicate with each other to solve problems (Norodahl \& Johannesson, 2016).

Many of us understood the benefits of outdoor. Classroom teaching focuses on the theory and conceptual understanding of terms, while the role of outdoor education is to improve the talents and potential of students (Harun \& Salamuddin, 2013). Furthermore, childhood nature experiences promote positive attitudes towards nature and wilderness (Ballew \& Omoto, 2018). Physical interaction with plants and animals in an outdoor environment, boost the memory and recall of learned content, as well as enhancing their interest and motivation (Broda, 2011). Association with any physical activity helps to improve balance, quicker reflexes, and stronger bones and muscles, as well as improves resilience and boost energy levels (Glettler \& Rauchb, 2020; Suzuki, 2017). It also develops specialized skills through outdoor learning, takes on a leadership role and furthermore, applying what is experienced to real-life lessons leads to a greater understanding of critical thinking skills (James \& Williams, 2017).

Past studies have been conducted in Malaysia regarding environmental knowl- 
edge and awareness, results showed that environmental level of knowledge were low amongst 16 years old students (Cheong 1980) and environmental awareness relates closely to academic achievement, students' gender, and socio-economic status (Fadzilah, 1999). A study conducted by Danny Parkin (1998) in Australia, on the other hand, confirmed that the relationship between outdoor education and environmental education should exist. In fact, many respondents also provided additional comments on the relationship between outdoor education and environmental education. For example, while it was important for participants to experience natural areas, it was equally important to preserve the natural areas where the activities take place.

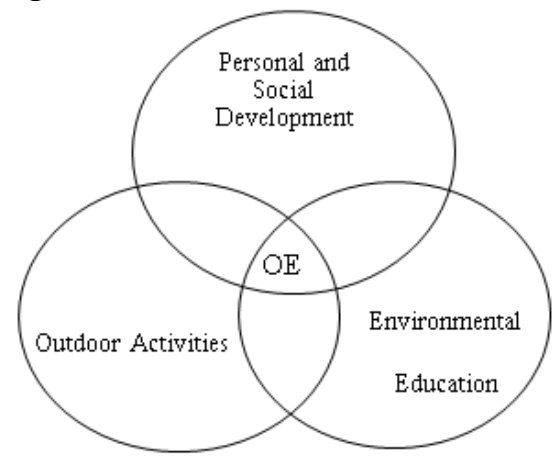

Figure 1. The Outdoor Education model (Higgins \& Loynes 1997)

The conceptual framework in Figure 1 illustrates the expectation of this study. The result of this approach applied in the outdoors is that the experience is to be effective as a means of personal and social development, and in increasing awareness of environment. Outdoor education has been described as a place (natural environment), a subject (ecological processes), and a reason (resource stewardship) for learning. It has been called a method (experiential), a process (sensory), and a topic (relationships) of learning stated by (Gilbertson, Bates, McLaughlin, \& Ewert, 2016). Since most of the outdoor activities take place in nature settings, most of the students are mostly exposed to different kinds of nature available in their area. So Outdoor Education should encompass all the elements that cover outdoor activities, but also personal and social development, as well environmental Education.

Therefore, this study seeks to investigate if students at a higher educational level appreciate nature through their involvement in outdoor programs and activities they enjoyed.

\section{METHOD}

A quantitative non-experimental research design was used in this research. Using a simple random sampling procedure, following Krejci And Morgan's Sample Size Determination Table, a total number of 169 students from semester 1 until 8 of Physical and Health Education students responded to the questionnaires. PHE students were chosen as they are active and familiar with outdoor education programs. First, students responded on questions regarding their Outdoor Activity Involvement, to determine the frequency or participation, followed by Likert-scale items of list of Outdoor Activities from two categories: water-based and land-based activities. Then, the last section covers the questions on knowledge and awareness towards Nature 
and Environmental Appreciation. The data from the questionnaire will be analyzed using quantitative research statistical analysis methods, which are descriptive statistics (mean, percentage, and standard deviation) to determine their outdoor activities and correlation was used to analyze the relationship between outdoor activity enjoyment with nature appreciation.

\section{RESULTS AND DISCUSSION}

Table 1. Demographic Profile

\begin{tabular}{ccc}
\hline Characteristics & Frequency $(\mathrm{N})$ & Percentage $(\%)$ \\
\hline Gender & & \\
Male & 94 & 56 \\
Female & 75 & 44 \\
Total & 169 & 100 \\
\hline Age & & \\
$18-20$ & 45 & 27 \\
$21-23$ & 83 & 49 \\
$24-26$ & 39 & 23 \\
$27-29$ & 2 & 1 \\
Total & 169 & 100
\end{tabular}

Table 1 illustrates the summary of respondents. A total of 169 students involved in this survey with 94 males (56\%) and 75 females (44\%). The range of age was from 18 to 29 years old, with the almost half $(49 \%)$ is between $21-23$ years old.

Table 2. Outdoor Adventure Involvement since leaving schools

\begin{tabular}{ccc}
\hline & Frequency $(\mathrm{N})$ & Percentage $(\%)$ \\
\hline Yes & 164 & 97 \\
No & 5 & 3 \\
Total & 169 & 100 \\
$<2$ times & 21 & 12.4 \\
2-4 times & 31 & 18.3 \\
$5-6$ times & 37 & 21.9 \\
$>10$ times & 80 & 47.3 \\
Total & 169 & 100 \\
\hline
\end{tabular}

Table 2 represents involvement in outdoor adventure and the frequency of involvement since they left schools. Most respondents (97\%) had the experience of involvement and about $80(47.3 \%)$ have participated more than 10 times. The high level of involvement in outdoor adventure instantiated the choice for being in the Physical and Health Education program, which requires active involvements in sports and other physical activities. This also indicates the continuous involvements whether it is done outside or during the study time at the university.

To further investigate their involvement, whether they enjoyed participating, a list of activities covering water-based and land-based activities were recorded. Table 
3 illustrates their overall involvement in water-based activity, while Table 4 is landbased, with 5 indicating strongly Agree, 4 - Agree, 3- Neutral, 2 - Disagree and 1- Strongly Disagree on the level of enjoyment in each activity participated.

Table 3 shows the list of water activities that are commonly involved by students whether during outdoor excursion or as leisure. The results which indicating five top mean scores of water activities range from Snorkeling with $(\mathrm{M}=4.29, \mathrm{SD}=.826)$ followed by kayaking $(\mathrm{M}=4.28, \mathrm{SD}=.893)$, Jet Skiing $(\mathrm{M}=4.20, \mathrm{SD}=.942)$ and Beach Volleyball $(\mathrm{M}=4.18, \mathrm{SD}=.984)$. Besides, there were two types of water activities that shared the same mean score that are Diving and Water Rafting activities $(M=4.16$, $\mathrm{SD}=.941)$ and $(\mathrm{M}=4.16, \mathrm{SD}=.928)$.

They also agreed that these activities gave them the enjoyment of participating, which include River Crossing $(\mathrm{M}=4.13, \mathrm{SD}=.955)$ followed by Water Confidence $(M=4.11, S D=1.003)$, Rowing $(M=4.04, S D=.960)$ and Water Skiing $(M=4.02$, $\mathrm{SD}=1.029)$. Other activities like Fish Viewing $(\mathrm{M}=3.99, \mathrm{SD}=1.006)$, Swimming in a lake, river, or the ocean $(\mathrm{M}=3.89, \mathrm{SD}=1.009)$, Water Surfing $(\mathrm{M}=3.82, \mathrm{SD}=1.084)$ Sailing $(\mathrm{M}=3.80, \mathrm{SD}=1.013)$ and fishing $(\mathrm{M}=3.66, \mathrm{SD}=1.035)$ indicate mean scores of lower than 4.00 but on average these activities somehow provide some pleasures to them.

Table 3. Enjoyment in Water-based Activities

\begin{tabular}{lcc}
\hline & Mean & Std. Deviation \\
\hline Fishing & 3.66 & 1.035 \\
Kayaking & 4.28 & .893 \\
Snorkelling & 4.29 & .862 \\
Diving & 4.16 & .941 \\
Sailing & 3.80 & 1.013 \\
Water rafting & 4.16 & .928 \\
Water confidence & 4.11 & 1.003 \\
River crossing & 4.13 & .955 \\
Water surfing & 3.82 & 1.084 \\
Beach Volleyball & 4.18 & .984 \\
Rowing & 4.04 & .960 \\
Swimming in a lake, river, or the ocean & 3.89 & 1.099 \\
Fish Viewing & 3.99 & 1.006 \\
Jet Skiing & 4.20 & .942 \\
Water skiing & 4.02 & 1.029 \\
\hline
\end{tabular}

The results represent the nature of students' backgrounds and the program that they enrolled. Among the main criteria of acceptance into the PHE program are active involvements in sports and other outdoor activities. Therefore, activities like swimming, rowing, fishing, and water confidence are routine in their school and college organized leisure programs. Water surfing and sailing are not common and are usually involved by professionals and not so popular in Malaysia due to the weather and where appropriate conditions exist. 
Table 4. Enjoyment in Land-Based Activities

\begin{tabular}{lcc}
\hline & Mean & Std. Deviation \\
\hline Hiking & 4.54 & .627 \\
Jungle trekking & 4.54 & .636 \\
Rock climbing & 4.35 & .796 \\
Abseiling/ rappelling & 4.31 & .809 \\
Orienteering & 4.00 & .945 \\
Camping & 4.46 & .740 \\
Hunting & 3.83 & 1.144 \\
Nature/wildlife watching & 4.54 & .607 \\
Survivor skills (e.g., cooking) & 4.30 & .822 \\
Rope course (e.g., knotting, high rope, low rope & 4.08 & 1.014 \\
Horseback Riding & 4.19 & .873 \\
Trail Walking/Running & 4.34 & .748 \\
Off-road driving (e.g., drive in the jungle) & 4.18 & .864 \\
Mountain/ trail or road cycling & 4.22 & .905 \\
\hline
\end{tabular}

The results in Table 4 showed the enjoyment gained from land-based activities. In general, the students agreed that almost all activities listed gave them the enjoyment needed while engaging. For example, Jungle Trekking $(M=4.54, S D=.636)$, Hiking $(M=4.54$, $\mathrm{SD}=.627)$ and Nature and Wildlife Watching $(\mathrm{M}=4.54, \mathrm{SD}=.607)$ gave the highest mean scores. This is followed by Camping $(\mathrm{M}=4.46, \mathrm{SD}=.740)$ and Rock Climbing $(\mathrm{M}=4.35$, $\mathrm{SD}=.796)$. Jungle trekking, hiking and wildlife watching are common activities during outdoor education programs and students are scheduled and encouraged to follow specific programs organized at the faculty or University levels. The landform of the country with its oldest rainforest and high hills are the reasons behind these popular outdoor activities.

The rest of the other activities which include Trail Walking/Running ( $\mathrm{M}=4.34$, $\mathrm{SD}=.748)$ followed by Abseiling or Rappelling $(\mathrm{M}=4.31, \mathrm{SD}=.809)$, Survivor Skills $(\mathrm{M}=4.30, \mathrm{SD}=.822)$, Mountain trail or Road Cycling $(\mathrm{M}=4.22, \mathrm{SD}=.905)$, Horseback Riding $(\mathrm{M}=4.19, \mathrm{SD}=.873)$, Off-road Driving $(\mathrm{M}=4.18, \mathrm{SD}=.864)$, Rope Course $(\mathrm{M}=4.08$, $\mathrm{SD}=1.014)$ and Orienteering $(\mathrm{M}=4.00, \mathrm{SD}=.945)$ were shown to provide some aspects of enjoyments to the students. Similarly, these activities are done in natural environment while some are administered at parks or commercial places run by leisure providers.

Finally, Hunting $(\mathrm{M}=3.83, \mathrm{SD}=1.144)$ activity does not seem to give any form of pleasure for the students. Because hunting may fall into various categories used to measure hunting participation, from the weapons used to the animals and habitats being hunted, hence, it is difficult for the students to indicate their enjoyment in hunting if it rarely partakes.

Table 5. Level of Awareness on Nature Appreciation

\begin{tabular}{lll}
\hline & \multicolumn{2}{l}{ Frequency } \\
\hline Conservation & Mean & Std. Deviation \\
Climate Change & 3.12 & .927 \\
Natural Resource and Management & 3.22 & .992 \\
Environmental Legislation & 3.01 & .910 \\
Environmental Activism & 2.94 & .884 \\
\hline
\end{tabular}


Table 5 shows the level of awareness based on the students' knowledge regarding nature information. The scales range from 1 - No knowledge, 2 - Not much, $3-$ Moderate, 4-A good amount, 5 - A lot. The higher the knowledge regarding nature the higher their level of awareness. Overall results indicate that most students have moderate knowledge regarding nature information. For example, the highest mean score is knowing the Climate Change $(\mathrm{M}=3.22, \mathrm{SD}=.992)$ followed by Environmental Activism ( $\mathrm{M}=3.17, \mathrm{SD}=.943)$, Conservation $(\mathrm{M}=3.12, \mathrm{SD}=.927)$, and Natural Resource and Management $(\mathrm{M}=3.01, \mathrm{SD}=.910)$. Not much information regarding Environmental Legislation that students are aware off with $\mathrm{M}=2.94(\mathrm{SD}=.884)$.

This represents moderate awareness regarding matters associated with nature. This is supported by the information gained in their demographic profile whereby only $9(94.7 \%)$ out of 169 students were involved or members in environmental organizations. This is supported by previous literature when environmental level of knowledge was low amongst 16 years old students (Cheong 1980).

Table 6. Pearson's Correlation between Activities and Nature Appreciation.

\begin{tabular}{llcc}
\hline & & Nature Appreciation & Activities \\
\hline \multirow{4}{*}{ Nature Appreciation } & Pearson Correlation & 1 & .234 \\
& Sig. (2-tailed) & & .002 \\
& $\mathrm{~N}$ & & 169 \\
& Pearson Correlation & .234 & 1 \\
Activities & Sig. (2-tailed) & .002 & \\
& $\mathrm{~N}$ & 169 & 169 \\
\hline
\end{tabular}

Correlation is significant at the 0.05 level (2-tailed).

Table 6 illustrates the findings of inferential analysis towards the relationship between activities and nature appreciation among 169 students. Pearson's correlation analysis was conducted to analyse if there is any significant relationship between overall activities that they enjoyed with appreciation towards nature. The analysis found that $r=.234$ and $p$-value $=.002$ which is smaller than .05. This indicates that there is a significant weak relationship between activities enjoyed with nature appreciation among Physical and Health Education students. In other words, as activity enjoyment increased, the level of nature appreciation should also increase.

The above finding is the summary of results from Water and Land-based activities and the relationship with nature. Initially, Pearson's correlation analysis was performed between each type of water-based activity with nature appreciation. The results showed that only five types of waterbased activities were significantly related with nature appreciation. The activities are Kayaking $(\mathrm{r}$ $=.171, \mathrm{p}$-value $=.027)$, Water Rafting $(\mathrm{r}=.157, \mathrm{p}$-value $=.041)$, River Crossing $(\mathrm{r}=.190, \mathrm{p}$-value $=.013)$, Beach Volleyball $(\mathrm{r}=.223, \mathrm{p}$-value $=.004)$ and Swimming in a lake, river, or the ocean $(\mathrm{r}$ $=.216, \mathrm{p}$-value $=.005)$ with $\mathrm{p}$-values are less than .05 and have significant relationship with nature and environmental appreciation.

Pearson's correlation analysis was conducted between each type of land-based activity with nature appreciation. Nine types of land-based activities were found to have significant relation with nature appreciation. The types of activities are Hiking $(\mathrm{r}=.229$, $\mathrm{p}$-value $=.003)$, followed by Jungle Trekking $(\mathrm{r}=.246$, $\mathrm{p}$-value $=.001)$, Rock Climbing $(\mathrm{r}=.250, \mathrm{p}$-value $=.001)$, Abseiling $/$ Rappelling $(\mathrm{r}=.163$, $\mathrm{p}$-value $=.034)$, Camping activity $(\mathrm{r}=.314$, $\mathrm{p}$-value $=.00)$, Nature and Wildlife Watching activity $(\mathrm{r}=.307$, $\mathrm{p}$-value $=.000)$, Survivor Course $(\mathrm{r}=.229$, $\mathrm{p}$-value $=.003)$, Rope Course $(\mathrm{r}=.174$, $\mathrm{p}$-value $=.023)$ and Trail Walking/Running activity $(\mathrm{r}=.262$, $\mathrm{p}$-value $=.001)$ respectively, with $\mathrm{p}$ values are less than .05 .

High level of involvements and significant enjoyment shown in various outdoor activities 
signify the role of $\mathrm{OE}$ in the life or young people. In several ways, $\mathrm{OE}$ enables a person to develop a good behavior, learn about team cohesion, leadership skills, knowledge, responsibility and appreciation to nature and environment. It is a type of learning system that involves challenging or adventurous activities as a means of promoting personal and social growth for individuals (Fiskum \& Jacobsen, 2012). Outdoor involvement not just focusing on applying skills needed, but also holistic development of an individual. As shown in results above, the connection of activities and nature appreciation happened because choices of activities usually take place in a versatile authentic learning environment such as lakes, forest, sea, mountain, and wilderness. Therefore, activities such as camping, jungle trekking, trail walking and mountain climbing as well as water activities are exciting and satisfying to the participants because these activities require direct involvement with nature and provide a meaningful experience for everyone.

Additionally, based on the descriptive analysis result, it clearly shown a higher level of enjoyment among Physical and Health Education students towards outdoor activities. This might be assumed that the teaching and content of the Outdoor Education subject involve many of the fun, challenging yet enjoyable activities such as camping. Camping can be said as an enjoyable activity as it involves a lot of students to join and having some camp activities together in a team. Furthermore, most of the students had experience in joining outdoor activities about more than 10 times since they left primary school, thus explain their diverse preferences and enjoyment in water and landbased activities.

It is important to ensure the connection between human and nature, the solution to curing the nature deficit-disorder as part of the reminder that people need to be educated on the imprtance of nature and environment in life. According to Warden (2018), nature-based curriculum is a wellresearched educational process as it supports the growth of children by integrating them with nature, rather than by withdrawing them from nature. So involvement in OE helps to develop awareness on nature and environmental if it starts from young age and can still be instilled during adolescents peroid with more consistent efforts in the content of delivery and frequency of engagement.

The researchers believed that through the involvement in OE program alone may not enough to create the value of appreciation towards nature in a deeper level though it does help create the awareness. Namely, instructors or program coordinators will keep reminding students on the safety aspects during outdoors, as well as making sure the place is not damaged and rubbish not thrown away. Therefore, it is important that in outdoor education, the experiences of participants encompass both the pedagogy and the content, just like learning other courses in Education. So, it should be educationally enough on nature appreciation through experiential learning. For instance, the elements of conservation, climate change because of deforestation, natural resources which include living resources like forests or non-living ones like wind, water, solar energy must be enlightened together with physical activities during outdoor education programs. Students should be educated on the importance of connecting to the natural world around, taking care of the environment, being comfortable in a natural environment, use outdoor as a place to deal with stress and to try new activities. Michelsen \& Fisher (2017) suggested that environmental education has been proven as an effective tool to shift the perceptions and behaviors of individuals towards more sustainable ones.

There are several recommendations relating to the OE program for future improvements. As educators and instructors play their roles in shaping the students through activities, the content can be improved through integrating together new area of studies related to mother nature such as learning about soil, trees, how to recognize the poison from the flowers, trees or animals, climate change, conservation, environmental legislation even basic on how to recognize unseen realities.

Moreover, OE program can encourage volunteerism among students with project collaborations with any environmental organizations available in Malaysia. Students are made aware of any latest information pertaining to nature threats and can join more organized outdoor activities for saving nature purposes. Therefore, nature experience and relationship with nature are vital for positive development of individuals and nature awareness towards environmental sustainability.

\section{CONCLUSION}

The study concluded that participating in Outdoor Education, having more involvements and enjoyments in variance of outdoor activities contribute positive attitudes towards nature and 
environmental appreciation. It does, directly when the activities are very much handled and focused on nature aspects in learning new skills. It will enhance if with proper guidelines, with good theory and practice incorporated in the content of outdoor education can help create better positive mind set and responsible individuals from early age towards nature appreciation and help to protect and care for the environment.

\section{REFERENCES}

Abdullah, A., Zakaria, S. Z., \& Razman, M. R. 2018. Environmental Education Through Outdoor Education for Primary School Children. International Journal of The Malay World and Civilisation, 6 (Special Issue 1): 27 - 34.

Ballew, M. T., \& Omoto, A. M. 2018. Absorption: How Nature Experiences Promote Awe And Other Positive Emotions. Ecopsychology, 26-35.

Booth, J. W., \& Neill, J. T. 2018. Coping Strategies and The Development of Psychological Resilience. Journal of Outdoor and Environmental Education, 47-54.

Broda, H. W. 2011. Moving the Classroom Outdoors: Schoolyard-Enhanced Learning In Action. Portland: Stenhouse.

Cheong, S. Y. 1980. Science and environmental orientations - A Malaysians case study. Presented in Eight Biennial Conference of AABE. Organized by Asian Association for Biology Education, Japan October, 16 - November, 1.

Fadzilah Muhammad Ali. 1999. Tahap kesedaran alam sekitar di kalangan pelajar sekolah rendah dan menengah: Satu kajian kes. Doctoral Thesis. Kuala Lumpur, Malaysia: Universiti Kebangsaan Malaysia

Fiskum, T. A., \& Jacobsen, K. 2012. Outdoor Education Gives Fewer Demands for Action Regulation and An Increased Variability of Affordances. Journal of Adventure Education \& Outdoor Learning, 1(24).

Gilbertson, K., Bates, T., Mclaughlin, T., \& Ewert, A. 2016. Outdoor Education: Methods and Strategies. Champaign, Illinois: Human Kinetics.

Glettler, C. \& Rauchb. F. 2020. Nature Learning - early childhood nature experience and sustainability education. Journal of Applied Technical and Educational Sciences, 10 (3): 5-22. doi. org/10.24368/jates.v10i3.202 19

Harun, M. T., \& Salamuddin, N. 2013. Applying Elements of Outdoor Education in Teacher Education Innovation. Asian Social Science, 9(16): 15-21. DOI: 10.5539/ass.v9n16p15

Hussein, H. 2010. Using the Sensory Garden as a Tool to Enhance the Educational Development and Social Interaction of Children with Special Needs. Support for Learning, 25 (1): 25 -31. https://doi.org/10.1111/j.1467-9604.2009.01435.x

James, J. K., \& Williams, T. 2017. School-Based Experiential Outdoor Education. Journal of Experiential Education, 40(1): 58-71.

Michelsen, G., \& Fisher, D. 2017. Sustainable Development Policy: A European Perspective. London, United Kingdom: Routledge.

Nadelson, L. S., \& Jordan, J. R. 2012. Student Attitudes Toward and Recall of Outside Day: An Environmental Science Field Trip. The Journal of Educational Research, 105(3): 220-231.

Norodahl, K., \& Johannesson, I. A. 2016. "Let's Go Outside":Icelandic Teachers' Views Of Using The Outdoors. Education 3-13, 44(4): 391-406.

Parkin, D. 1998. Is outdoor education environmental education? International Journal of Environmental Education and Information, 17(3): 275-286.

Priest, S. 1990. The Semantics of Outdoor Education. Adventure Education State College, PA: Venture Publishing.

Suzuki, D. 2017. World Environment Day Reminds Us to Reconnect with Nature. Retrieved From Retrieved from http://www.Davidsuzuki.Org/Blogs/Sciencematters/2017/06/World-Environment-Day-Reconnect-With-Nature/

Warden, C. 2018. Nature Pedagogy: A Common Thread Connecting Nature-Based Settings Worldwide. Retrieved from https://Naturalstart.Org/Feature-Stories/Nature-Pedagogycommon- ThreadConnecting-Nature-Based-Settings-Worldwide 